УДК 631.348.4

DOI: 10.36461/NP.2019.52.3.019

\title{
ИССЛЕДОВАНИЯ ПРОТРАВЛИВАТЕЛЯ МОВІTОХ SUPER, ОСНАЩЕННОГО ДВУХДИСКОВЫМ РАСПРЕДЕЛЯЮЩИМ УСТРОЙСТВОМ И ДВУХУРОВНЕВЫМ ОТРАЖАЮЩИМ УСТРОЙСТВОМ
}

А. В. Мачнев*, доктор техн. наук, доцент; О. Н. Кухарев, доктор техн. наук, професссор;

О. Ю. Мачнева, аспирант; В. А. Мачнев, доктор техн. наук, профрессор;

П. Н. Хорев, канд. техн. наук, доцент; А. В. Яшин канд. техн. наук, доцент

*Федеральное государственное бюджетное образовательное учреждение высшего образования «Московский государственный университет пищевых производств», г. Москва, Россия;

Федеральное государственное бюджетное образовательное учреждение высшего образования «Пензенский государственный аграрный университет», Россия,

т. (8412) 62-85-79, e-mail: mav700@mail.ru

Применение протравливателей семян способствует повышению их полевой всхожести, снижению головневых заболеваний и корневых гнилей. Опыт эксплуатации протравливателей в зерносеющих хозяйствах показал, что в Российской Федерации наибольшее распространение получили самоходные протравливатели камерного типа ПС-20AM01, Mobitox Super, ПСК-15. Недостатки этих машин выражаются в невозможности проведения качественного протравливания на площадках с углом наклона более 7 градусов и при работе машины при производительности в диапазоне от 60 до $100 \%$ от базовой. Кроме того, повышенные влажность семян после протравливания (по агротехническим требованиям АТТ не более $1 \%)$ и дробление семян несколько снижают эффективность применения камерных протравливателей. Целью исследований являлось повышение качества протравливания семян за счет применения двухдискового распределяющего и двухуровневого отражающего устройств. Для чего сравнительные исследования протравливателя Mobitox Super, оснащенного двухдисковым распределяющим устройством и двухуровневым отражающим устройством семян, проводили с базовым вариантом Mobitox Super в ООО «Русское поле» Сердобского района Пензенской области на обработке семян озимой пшеницы Бирюза комбинированным инсектофунгицидным протравителем семян Селект Макс с нормой расхода препарата 1,7 л/т. Установлено, что в диапазоне от 30 до 150 мм открытия заслонки лепесткового дозатора разработанного камерного самоходного протравливателя качество протравливания семян значительно увеличивается в сравнении с серийно-выпускаемым Mobitox Super и yвеличивается его производительность до 2,1 т/ч.

Ключевые слова: протравливатель, семена, распределяющее устройство, двухуровневое отражающее устройство, распыливающее устройство, рабочий раствор, дробление семян, полнота протравливания.

\section{Введение}

Протравливание семян - одна из обязательных операций перед посевом, которую проводят самоходными или стационарными протравливателями с применением протравителей (концентрата рабочей жидкости). Существующие протравливатели семян выпускаются непрерывного и периодического действия, а по типу распределяюще-распыливающих устройств шнековые, камерные или барабанные [1-7, 9, 11-13]. Установлено, что применение протравливателей семян способствует повышению полевой всхожести семян, снижению головневых заболеваний и корневых гнилей семян. Кроме того, перед протравливанием семена необходимо тщательно очищать и сортировать, то есть чистота семян должна составлять не менее $98 \%$, всхожесть - $96 \%$. Анализ научных работ, посвященных повышению качества предпосевной обработки семян и опыт эксплуатации протравливателей в зерносеющих хозяйствах показали, что в Российской Федерации наибольшее распространение получили самоходные протравливатели камерного типа ПС-20AM01, Mobitox Super, ПСК-15. Это связано с проведением протравливания семян на территории зерносеющих хозяйств. Однако, им присущи и недостатки, которые выражаются в невозможности проведения качественного протравливания на площадках с углом наклона более 7 градусов, и при работе машины 
производительностью 60-100 \%. Кроме того, повышенные влажность семян после протравливания (по агротехническим требованиям АТТ не более 1 \%) и их дробление несколько снижают эффективность применения камерных протравливателей. Поэтому исследования, направленные на устранение вышеперечисленных недостатков актуальны и своевременны [1-15].

Широкое распространение в нашей стране получили протравители фрирм «Syngenta», «Basf», «Avgust» и «Bayer», доля которых на рынке составляет до $70 \%$. Следует отметить, что выбор фрирм агрономами строится случайным образом или на рекомендациях коллег [1-9, 11-13].

\section{Методы и материалы}

Для устранения вышеперечисленных недостатков нами разработан камерный самоходный протравливатель семян (рис. 1), оснащенный двухдисковым распределяющим устройством и двухуровневым отражающим устройством семян, включающий в себя раму, опорное и приводные колеса самохода, поперечный и продольный подающие шнеки, трубопровод сброса лишних семян, модуль дозированного смешивания, состоящего из загрузочного бункера для семян, лепесткового дозатора, камеры протравливания с верхним кольцевым и нижним сплошным дисков, оснащенных направителями семян с криволинейными рабочими поверхностями, отражающим устройством верхнего и нижнего уровня семян цилиндрической фрормы, трехдисковым распыливающим устройством рабочей жидкости, бак рабочей жидкости, на- coc eе подачи, запорную и регулирующую арматуру, выгрузной шнек, щиток управления протравливателя. Привод верхнего кольцевого и нижнего сплошного дисков осуществляется посредством вала от электродвигателя мощностью 0,8 кВт, а трехдискового распыливающего устройства рабочей жидкости - навстречу вращения двухдиского распределяющего устройства семян. Потребная мощность протравливателя 3,9 кВт $[5,6,8]$.

Сравнительные исследования протравливателя Mobitox Super, оснащенного двухдисковым распределяющим устройством и двухуровневым отражающим устройством семян проводили с базовым вариантом Mobitox Super в OOO «Русское поле» Cердобского района Пензенской области на обработке семян озимой пшеницы Бирюза с периодом вегетации 289-325 дней, комбинированным инсектофунгицидным протравителем семян Селект Макс с нормой расхода препарата 1,7 л/т. Для приготовления рабочей жидкости заполняли бак протравливателя водой на 1/3 объема и добавляли требуемое количество препарата, размешенного в отдельной емкости. Затем выливали маточный раствор препарата в бак и дополняли водой до требуемого объема. Рабочий раствор необходимо использовать в течении одних суток. При этом расстояние от кольцевого верхнего диска до отражателя верхнего уровня составляло 60 мм, диаметр отражателя нижнего сплошного диска - 350 мм, высота расположения верхнего отражателя - 30 мм, высота установки нижнего отражателя - 30

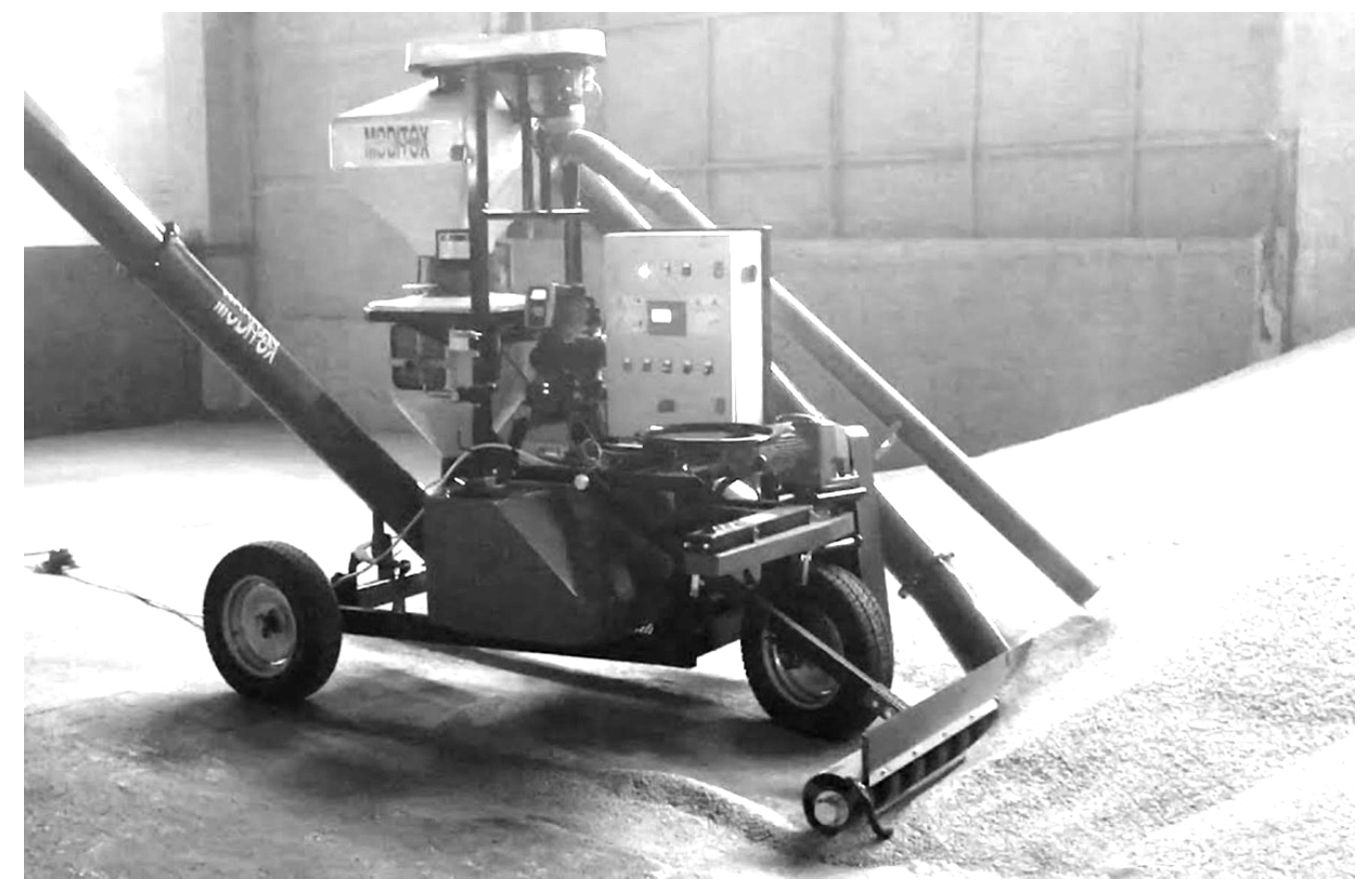

Puc. 1. Общий вид работы протравливателя Mobitox Super, оснащенного двухдисковым распределяющим устройством и двухуровневым отражающим устройством семян 
мм. Данные получили в ходе проведения теоретических и лабораторных исследований предлагаемого протравливателя [5, 6, 8]. Исследования проводились с использованием отраслевого стандарта СТО АИСТ 10.4-2010 «Испытания сельскохозяйственной техники. Машины для подготовки семян. Методы оценки фрункциональных показателей» [10].

\section{Результаты}

В результате проведения исследований установлено, что подача семян разработанного и базового протравливателя семян одинакова, что связано с открытием заслонок (лепесткового дозатора) на одно и то же выходное сечение. Кроме того, установлена зависимость (рис. 2) диаметра лепесткового дозатора $(30,50,70,90,110$, 130 и 150 мм) на неравномерность подачи семян разработанного протравливателя Mobitox Super, оснащенного двухдисковым распределяющим устройством и двухуровневым отражающим устройством семян с базовым Mobitox Super.

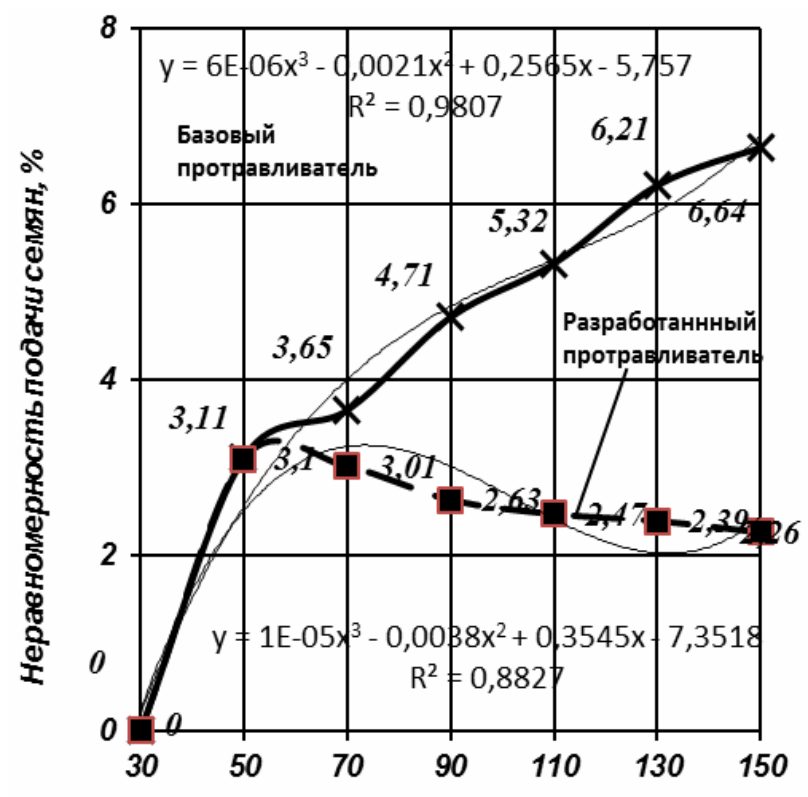

Диаметр лепесткового дозатора, мм

Puc. 2 Зависимость диаметра лепесткового дозатора на неравномерность подачи семян разработанного протравливателя Mobitox Super, оснащенного двухдисковым распределяющим устройством и двухуровневым отражающим устройством семян с базовым Mobitox Super

Результаты исследований по определению влияния диаметра лепесткового дозатора на неравномерность подачи семян разработанного протравливателя Mobitox Super, оснащенного двухдисковым распределяющим устройством и двухуровневым отражающим устройством семян с базо- вым Mobitox Super показали, что при открытии заслонки лепесткового дозатора на 70 мм у разработанного протравливателя неравномерность подачи семян ниже на 0,55\%, а при открытии на 100-150 мм неравномерность распределения семян базовым протравливателем не отвечает агротехническим требованиям, предъявляемых к протравливанию ( $\pm 5 \%)$ и составляет более $5 \%$. Кроме того, результаты сравнительных исследований разработанного протравливателя Mobitox Super, оснащенного двухдисковым распределяющим устройством и двухуровневым отражающим устройством семян с базовым Mobitox Super, показали снижение дробления семян разработанным протравителем до 0,07\%, по сравнению с 0,12 \% у базового, влажности семян после протравливания с 15,0\% до $14,5 \%$, при увеличении полноты протравливания на $11,8 \%[10,11]$.

Расчет экономической эффективности применения разработанного протравливателя Mobitox Super, оснащенного двухдисковым распределяющим устройством и двухуровневым отражающим устройством семян подтвердили целесообразность его применения. Так, несмотря на увеличение дополнительных затрат на модернизацию в размере 17,2 тыс. руб. производительность разработанной машины за час сменного времени повысилась на 2,1 т/ч при максимальном открытии заслонки лепесткового дозатора, годовые эксплуатационные затраты на протравливание семян снизились на 2 тыс. руб., при сроке окупаемости дополнительных затрат на модернизацию 0,1 года.

\section{Заключение}

Для разработанного камерного самоходного протравливателя с применением двухдискового распределяющего и двухуровневого отражающего устройств сумма дополнительных затрат увеличивается в сравнении с серийно-выпускаемым Mobitox Super на 17,2 тыс. руб. при снижении годовых эксплуатационных затрат на протравливание на 2 тыс. руб. за счет повышения качества протравливания и производительности на 2,1 т/ч. Установлено, что в диапазоне открытия заслонки лепесткового дозатора от 30 до 150 мм качество протравливания семян увеличивается, а именно: неравномерность подачи семян не превышает агротехнических требований и составляет не более $3,11 \%$; дробление семян снижается на $0,05 \%$; полнота протравливания увеличивается на $11,8 \%$; влажность семян после протравливания снижается на 0,5\%. 


\section{Лuтература}

1. Байгускаров, М. Х. Исследование поведения зерна в эксцентрично закрепленном барабане протравливателя семян / М. Х. Байгускаров, Э. Р. Хасанов // Вестник Башкирского государственного аграрного университета. - 2010. - № 4. - С. 35-39.

2. Бурмистров, А. Н. Современные протравливатели семян зерновых культур / А. Н. Бурмистров, В. А. Вялых // APK News. - 2018. - № 5. - С. 44-46.

3. Вялых, В.А. Совершенствование технологической схемы протравливателя семян зерновых культур / В. А. Вялых, А. Н. Бурмистров, В. Т. Алехин // Защита и карантин растений. -2018. - № 2. - C. 26-28.

4. Зайнутдинов, И.Р. Экспериментальное исследование производительности пневмозагрузочного устройства для протравливателей семян / И. Р. Зайнутдинов, Э. Г. Нуруллин // Актуальные вопросы совершенствования технологии производства и переработки продукции сельского хозяйства. - 2019. - № 21. - С. 516-519.

5. Исследование взаимодействия семян с распределяющим и отражающим устройствами / О. Ю. Мачнева, В. С. Каблуков, О. Н. Кухарев и др. // Вестник Рязанского государственного агротехнологического университета им. П. А. Костычева. - 2018. - № 4 (40). - С. 73-78.

6. Мачнев, А. В. Исследования взаимодействия семени с направителем двухдискового распределяющего устройства протравливателя семян / А. В. Мачнев, В. С. Каблуков, О. Ю. Мачнева // Наука в центральной России. - 2016. - № 4 (22). - С. 40-51.

7. Опиев, О. И. К определению формы образующей стенки дозатора устройства для обработки семян защитно-стимулирующими веществами / О. И. Опиев, А. А. Серегин, В. В. Серегина // Вестник аграрной науки Дона. -Зерноград: ФГОУ ВПО АЧГАА. - 2010. - Вып. 1. - С. 22-27.

8. Программа и методика исследований распределяющего устройства камерного протравливателя / О. Ю. Мачнева, О. Н. Кухарев, В. С. Каблуков и др. // Инновационные идеи молодых исследователей для АПК России: сборник статей Всероссийской научно-практической конференции молодых ученых. Том ІІІ / Пензенский ГАУ. - Пенза: РИО ПГАУ, 2017. - С. 88-90.

Салахов, И. М. Энергосберегающий протравливатель семян / И. М. Салахов, Э. Г. Нуруллин // Сельский механизатор. - 2013. - № 11. - С. 16-17.

10. СТО АИСТ 10.4-2004. Испытания сельскохозяйственной техники. Машины для подготовки семян. Методы оценки функциональных показателей. - Введ. 01.06.2005. - Москва: ФГНУ РосНИИТиМ, 2005. - 39 с.

11. Тришкина, Д. С. Справочник агронома по вопросам протравливания семян зерновых культур / Д. С. Тришкина. - Москва, 2006. - 42с.

12. Хасанов, Э. Р. Обоснование конструктивно-технологических параметров протравливателя семян зерновых культур / Э. Р. Хасанов // Вестник Орловского государственного аграрного университета. - 2017. - № 2 (65). - С. 106-113.

13. Хасанов, Э. Р. Определение конструктивных параметров барабанного протравливателя семян при нестационарном режиме его работы / Э. Р. Хасанов, М. Х. Байгускаров // Вестник Ульяновской государственной сельскохозяйственной академии. - 2012. - № 4 (20). - С. 138-142.

14. Kukharev, O. N. GruBwort der Agrara-kademie Pensa / O. N. Kukharev, A. V. Schatova // Festschrift zum 25 jahrigen Bestehen Hochschule Neu-brandenburg: STEFFEN MEDIA, Friedland. - 2016. - S. 32.

15. Kukharev, O. N. The technology of obtaining high-quality seeds of sugar beet / O. N. Kukharev, A. V. Polikanov, I. N. Semov // Research journal of pharmaceutical, biological and chemical sciences. 2017. - V. 8. - № 1. - p. 1210-1213.

UDC 631.348 .4

DOI: 10.36461/NP.2019.52.3.019

\section{RESEARCH OF MOBITOX SUPER SEED DRESSING MACHINE, FITTED WITH A TWO DISC DISTRIBUTOR AND A TWO-LEVEL REFLECTIVE DEVICE}

A. V. Machnev*, Doctor of Technical Sciences, assistant-professor; O. N. Kukharev, Doctor of Technical Sciences, professor; O. Yu. Machneva, postgraduate; V. A. Machnev, Doctor of Technical Sciences, professor; P. N. Horev, Candidate of Technical Sciences, assistant-professor; A. V. Yashin Candidate of Technical Sciences, assistant-professor

${ }^{*}$ Federal State Budgetary Educational Institution of Higher Education «Moscow State University of Food Production», Moscow, Russia;

Federal State Budgetary Educational Institution of Higher Education «Penza State Agrarian University», Russia, t. (8412) 62-85-79, e-mail: mav700@mail.ru

The use of seed dressers improves their field germination, reduces smut diseases and root rot. The experience of the use of dressing agents in grain-sowing farms showed that the self-propelled seed dressers PS-20AM01, Mobitox Super, PSK-15 are most widely used in the Russian Federation. 
The disadvantages of these machines are expressed in the impossibility of conducting high-quality dressing on sites with an inclination angle of more than 7 degrees and when the machine is operating at a capacity in the range from 60 to $100 \%$ of the base. In addition, the increased moisture content of the seeds after dressing (according to the agrotechnical requirements of perfectly rigid body (PRB) - no more than $1 \%$ ) and the crushing of seeds somewhat reduce the effectiveness of using chamber dressers. The aim of the research was to improve the quality of seed dressing through the use of a two-disk distributing and a two-level reflecting devices. We conducted comparative studies of the Mobitox Super seed dresser, equipped with a two-disk distributor and a two-level seed reflector, with the basic version of Mobitox Super. The studies were carried out in the OOO «Russkoye Polye» of Serdobsky district of the Penza region on the treatment of winter wheat Biryuza seeds with a combined insectofungic seed dresser Select Max with a consumption rate of $1.7 \mathrm{l} / \mathrm{t}$. It was established that in the range from 30 to 150 $\mathrm{mm}$ of opening the spade-type dispenser flap of the developed chamber self-propelled seed dresser, the quality of seed dressing significantly increased and its productivity increased to $2.1 \mathrm{t} / \mathrm{h}$ in comparison with the commercially available Mobitox Super.

Key words: seed dresser, seeds, distributor, two-level reflecting device, sprayer, spray material, seed crushing, completeness of dressing.

\section{References:}

1. Bayguskarov, M. Kh. Investigation of grain behavior in an eccentrically fixed drum of a seed dresser / M. Kh. Bayguskarov, E. R. Khasanov // Bulletin of Bashkir State Agrarian University. - 2010. No. 4. - p. 35-39.

2. Burmistrov, A. N. Modern seed dressers for grain crops / A. N. Burmistrov, V. A. Vyalykh // APK News. - 2018. - No. 5. - p. 44-46.

3. Vyalykh, V. A. Improving the technological scheme of the seed dresser of grain crops / V. A. Vyalykh, A. N. Burmistrov, V. T. Alyokhin // Zashchita i karantin rasteniy. - 2018. - No. 2. - p. 26-28.

4. Zainutdinov, I. R. An experimental study of the performance of a pneumatic loading device for seed dressers / I. R. Zainutdinov, E. G. Nurullin // Actual issues of improving the technology of production and processing of agricultural products. - 2019.-- No. 21. - p. 516-519.

5. The study of the interaction of seeds with distributing and reflecting devices / $\mathrm{O}$. Yu. Machneva, V. S. Kablukov, O. N. Kukharev and others // Bulletin of Ryazan State Agrotechnological University n. a. P. A. Kostychev. - 2018.-- No. 4 (40). - p. 73-78.

6. Machnev, A. V. Investigation of the interaction of the seed with the guide of a double-disc distribution device for seed treatment / A. V. Machnev, V. S. Kablukov, O. Yu. Machneva // Science in Central Russia. - 2016. - No. 4 (22). - p. 40-51.

7. Opiev, O. I. On the determination of the shape of the generatrix of the dispenser of a device for treating seeds with protective-stimulating substances / O. I. Opiev, A. A. Seregin, V. V. Seregina // Bulletin of agricultural science of the Don. -Zernograd: FSEI HPE AchSAA. - 2010. - Issue. 1. - p. 22-27.

8. The program and methodology for studying the distribution device of the chamber dresser / O. Yu. Machneva, O. N. Kukharev, V. S. Kablukov and others // Innovative ideas of young researchers for the agricultural sector of Russia: collection of articles of the All-Russian scientific and practical conference of young scientists. Volume III / Penza SAU. - Penza: RIO PSAU, 2017.-- p. 88-90.

9. Salakhov, I. M. Energy-saving seed dresser / I. M. Salakhov, E. G. Nurullin // Selskiy Mechanizator. -2013 . - No. 11. - p. 16-17.

10. STO AIST 10.4-2004. Tests of agricultural machinery. Machines for the preparation of seeds. Methods for assessing functional indicators. - Introduction. 06/01/2005. - Moscow: Federal State Budget Scientific Institution RosNIITiM, 2005.-- 39 p.

11. Trishkina, D. S. Agronomist reference for seed dressing of grain crops / D. S. Trishkina. - Moscow, 2006. -42 p.

12. Khasanov, E. R. Justification of the design and technological parameters of the seed dresser of grain crops / E. R. Khasanov // Bulletin of Oryol State Agrarian University. - 2017. - No. 2 (65). - P. 106-113.

13. Khasanov, E. R. Determination of design parameters of a drum seed treater under unsteady mode of its operation / E. R. Khasanov, M. Kh. Bayguskarov // Bulletin of Ulyanovsk State Agricultural Academy. - 2012. - No. 4 (20). - p. 138-142.

14. Kukharev, O. N. GruBwort der Agrara-kademie Pensa / O. N. Kukharev, A. V. Schatova // Festschrift zum 25 jahrigen Bestehen Hochschule Neu-brandenburg: STEFFEN MEDIA, Friedland. - 2016. S. 32.

15. Kukharev, O. N. The technology of obtaining high-quality seeds of sugar beet / O. N. Kukharev, A. V. Polikanov, I. N. Semov // Research journal of pharmaceutical, biological and chemical sciences. 2017. - V. 8. - № 1. - p. 1210-1213. 